\title{
The Prevalence of Asymptomatic Gallstones in Relation to Fasting Gallbladder volume in Type 2 Diabetic Patients
}

\author{
Dr. Imad H. Tahir \\ Thi - Qar Health Directorate / Al - Nasiryia Diabetic and Endocrine Center
}

\begin{abstract}
Background: The sustained effect of poor glycemic control in diabetics results in a wide array of end-organ damage as a result of small and large vessels pathology. Mortality and morbidity are related to the progress of this damage but often there are acute metabolic deteriorations "1". Autonomic neuropathy (sympathetic or parasympathetic) typically accompanies other chronic complications of DM and may play a pathogenic role through disturbed regulation of local blood flow and affecting many systems in the body including the gastrointestinal leading to(hypermotility or hypo-motility of different organs leading to diarrhea, constipation, gastroparesis and gall bladder hypo-motility). The gallbladder tone is maintained by the vagal activity, but the sympathetic activity has little or no effect on the gallbladder " 5 ". Due to autonomic neuropathy, the contraction of gallbladder is poor resulting in hypo-motility, impaired gall-bladder emptying and biliary stasis “13,14", resulting in increased gallbladder volume, which predispose to gallstones formation “15". Aim of study: to evaluate the prevalence of asymptomatic gallstones in relation to of FGBV in type 2 diabetics. Subjects and methods: 47 patient with type 2 DM were included in this study ( 37 patients were women and 10 patients were men). At first, we studied the presence of gallstones and then we divided the subjects into two groups, those who have gallstones and those who haven't gallstones. Thereafter, we evaluated the fasting gall bladder volume (FGBV) in each group to study the relation between the presence of gallstones and the volume of the gallbladder in the fasting state. other parameters were studied in both groups including ( gender, age, BMI, duration of DM, serum cholesterol and TG, cigarettes smoking, family history of gallstones and HbA1c). Result and discussion: In this study that studied two diabetic groups, one of group with gallstones and the other have no gallstones, we found that in the diabetic group without gallstones, $69.7 \%$ of the patients were women, while all the diabetics with gallstones $(100 \%)$ were women with a significant difference $(\mathrm{P}$-value $=0.020)$. The study also shows that diabetics group with gallstones have higher FGBV levels than diabetics without gallstones as most of the diabetics with gallstones $(35.7 \%)$ have FGBV in the reference range of $\left(21-30 \mathrm{~mL}^{3}\right), 35.7 \%$ have FGBV in the reference range of $\left(31-40 \mathrm{~mL}^{3}\right)$, while most of the diabetics without gall-stones have FGBV levels less than $20 \mathrm{~mL}^{3}$ with significant difference between the two groups (P-value=0.0004). Conclusion: The prevalence of asymptomatic gallstones is higher in diabetic patients with higher levels of FGBV than in diabetics with lower FGBV levels especially in women.
\end{abstract}




\section{Background}

Diabetes mellitus(DM)is a syndrome with disordered metabolism and inappropriate increase in blood sugar (hyperglycemia) due to an absolute(as in type $1 \mathrm{DM}$ ) or relative (as in type 2 DM)deficiency of insulin. The sustained effect of poor glycemic control results in a wide array of end-organ damage as a consequence of small and large vessels

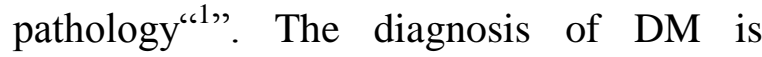
readily entertained when a patient presents with classic symptoms of DM (polyuria, thirst, polydipsia, polyphagia, and weight loss). The American Diabetes Association(ADA) put diagnostic criteria for the diagnosis of DM that include the following ( in addition to symptoms of DM ) “2” :

- Have a fasting plasma glucose (FPG) level of $\geq 126 \mathrm{mg} / \mathrm{dL}(7.0 \mathrm{mmol} / \mathrm{L})$, or

- Have a 2-hour plasma glucose level of 200 $\mathrm{mg} / \mathrm{dL}$ (11.1 mmol/L) or higher during a 75gram oral glucose tolerance test ( OGTT ), or

- Have a random plasma glucose of 200 $\mathrm{mg} / \mathrm{dL}$ ( $11.1 \mathrm{mmol} / \mathrm{L}$ )or higher .

- Have a HbA1c that is $6.5 \%$ or higher.

Glycemic control and chronic complications of DM: A reasonable aim of therapy in DM is to approach normal glycemic excursions without provoking severe or frequent hypoglycemia. Acceptable level of glycemic control includes blood glucose levels of $90-130$ $\mathrm{mg} / \mathrm{dL}$ before meals and after an overnight fast, and levels not higher than $180 \mathrm{mg} / \mathrm{dL}$ 1hour after meals and $150 \mathrm{mg} / \mathrm{dL} 2$ hours after meals. HbA1c levels should be not more than $1 \%$ above the upper limit of the normal range for any particular laboratory “3",. Late manifestation of DM include a number of pathologic changes that involve small and large blood vessels. these lesions lead to hypertension, end stage chronic kidney disease, blindness, autonomic and peripheral neuropathy, amputations of the lower extremities, myocardial infarction (MI), and cerebrovascular accidents (CVA). Autonomic neuropathy (sympathetic or parasympathetic) typically accompanies other chronic complications of DM and may play a pathogenic role through disturbed regulation of local blood flow and affecting many systems in the body “4" including: the cardiovascular system abnormalities like (resting tachycardia, diminished heart rate variability, prolonged QTc, silent myocardial ischemia, postural hypotension), genito-urinary system( impaired parasympathetic innervations leads to urinary bladder hypotonia, incomplete bladder emptying, dribbling of urine, and overflow incontinence, and erectile dysfunction which is commonly seen in diabetic patients), sudomotor dysfunction (abnormal sweat production in diabetic patients can result in xerosis and cracking of the skin, and predisposing these patients to cutaneous infections). Gastrointestinal tract is one of the most commonly affected systems by the autonomic neuropathy where altered 


\section{Email:utjmed@utq.edu.iq}

gastrointestinal function is commonly seen in DM. The most common clinical syndrome is Constipation, Diarrhea is another frequent complaint and can be caused by a variety of conditions including hyper-motility (impaired sympathetic inhibition), hypo-motility with bacterial overgrowth, pancreatic insufficiency, and bile salt irritation. Also gastro-paresis is a particularly disabling condition, often presenting with bloating, early satiety, nausea, and vomiting.

Gallbladder: The gallbladder is a pearshaped sac lying under the right hemi-liver . The bile is secreted by the in amount ranging from 1-2 liters daily. The gallbladder tone is maintained by the vagal activity, but the sympathetic activity has little or no effect on the gallbladder “ 65 ".

\section{Pathogenesis and etiology of} cholelithiasis: There are three main factors that inter-play and lead to formation of cholesterol gallstones, these factors include (1) cholesterol super-saturation of the bile, (2) nucleation, and (3) hypo-motility of the gallbladder. The liver is the most important organ that regulate the total body cholesterol store. Once secreted, cholesterol, which is insoluble in water, is solubilized in bile by forming mixed micelles with bile acids and phospholipids. As the bile becomes more saturated with the cholesterol, aggregation of microscopic cholesterol molecules will take place leading to formation of coalescent vesicles that crystallized (nucleation). Gradual deposition of additional layers of cholesterol leads to the appearance of macroscopic stones. Nucleation is

\section{Web Site: https://imed.utq.edu.iq}

influencing by many factors including: bile transit time, gallbladder contraction, bile composition (concentration of cholesterol, phospholipids, and bile salts), and the presence of bacteria, mucin, and glycolproteins, which act as a nidus that initiate the formation of cholesterol crystals. The formation of cholesterol gallstones in the super-saturated bile may be determined by the interplay between the pro-nucleating and anti-nucleating factors “6"”. Different types of gallstones (cholesterol gallstones, black pigment gallstones, and brown pigment gallstones) have different pathogenesis and different risk factors “7”, Cholesterol gallstones are associated with female sex, European and native American ancestry and increasing age. Other risk factors include ( obesity, pregnancy, gallbladder stasis, drugs, and heredity ). The metabolic syndrome of truncal obesity, insulin resistance, type 2 DM, hypertension, and hyperlipidemia is associated with increased hepatic cholesterol secretion and it is a major risk factor for the development of cholesterol gallstones. Cholesterol gallstones are more common in women who have experienced multiple pregnancies where the higher progesterone level is thought to be a major contributing factor as the progesterone decreases the gallbladder contractility leading to prolonged retention and greater concentration of bile in the gallbladder. About $25 \%$ of the predisposition to cholesterol GS appear to be hereditary, as judged from studies of identical and fraternal twins. At least a dozen of genes may contribute to the risk “8". Black and brown pigment gallstones occur disproportionately in individuals with 
high heme turnover. Disorders of hemolysis associated with gallstones include ( sickle cell anemia, hereditary spherocytosis, and beta-thalassaemia ).

Clinical features and complications of gallstones: Most patients with gallstones are asymptomatic. The clinical manifestation of gallstones can include episodic pain, acute cholecystitis, or obstructive jaundice, cholangitis, and pancreatitis, the latter three complications resulting from gallstones migration into the common bile duct " 9 ".

Diagnosis of gallstones: Different diagnostic procedures are used for the diagnosis of gall bladder diseases like (abdominal x-ray, abdominal ultasonography, abdominal computed tomography, radionuclide imaging or cholescintigraphy, cholecystography, ERCP and percutaneous transhepatic cholangiography), but the abdominal ultrasonography is the diagnostic procedure of choice for diagnosing ggallstones because it is rapid and accurate and can be used in patients with liver dysfunction and jaundice. The abdominal ultrasonography is most accurate if the patient fast overnight so that the gallbladder is distended. Ultrasonund studies based on analysis of reflected sound waves. Abdominal ultrasonography can detect the gall bladder calculi with $95 \%$ accuracy “ 10 ,.

\section{Association between DM and gallstones:}

Many studies worldwide revealed that diabetic patients are two to three times more risky for gallstones than nondiabetics“"11", Diabetes was reported to be frequently associated with inflammation of biliary tract and cholelithiasis “"12", The definite cause of gallstones in DM is not well clarified. However, due to autonomic neuropathy, the contraction of gallbladder is poor resulting in hypo-motility, impaired gallbladder emptying and biliary stasis "13, 14",resulting in increased gallbladder volume, which predispose to gallstones formation“"15". Obesity,hypertriglyceridemia“" 16,, which are frequently reported in diabetic patients, are predisposing factors for gallstones formation.

Aim of Study: To evaluate the prevalence of asymptomatic gallstones in relation to fasting gallbladder volume in type 2 diabetic patients.

Subjects and Methods: In this cross sectional study which is done in The-Qar center for diabetes and endocrine diseases in Iraq / Annasiriyah extended from June/ 2016 to December/2016, 47 patient with type $2 \mathrm{DM}$ were included, 37 patients were women and 10 patients were men. At first, we studied the presence of gall stones and then we divided the subjects into two groups, those who have gallstones and those who haven't gallstones. Thereafter, we evaluated the fasting gall bladder volume (FGBV) in each group to study the relation between the presence of gallstones and the volume of the gallbladder in the fasting state.

Inclusion and exclusion criteria: This study included diabetic patients of both ( male and female) sexes of age eighteen years and more. While it excluded :

1- Pregnant ladies. 


\section{Email:utjmed@utq.edu.iq}

2- Those patient with hepatic or biliary diseases.

3- Patients with haemolytic anaemia.

4- Patients with ascites.

5- Ladies taking oral contraceptive pills.

In both groups, I recorded the patient's age, sex, body mass index (BMI), duration of DM, HbA1c level, family history of gallstones, serum lipid profile and cigarettes smoking history to study their relation to the presence of gallstones.

The FGBV is evaluated in both groups after eight to twelve hours of fasting with a 2D ultrasound machine using a five $\mathrm{MHz}$ transducer. All the patients also scanned for any hepatic or biliary diseases to
Web Site: https://imed.utq.edu.iq

exclude any patient with these diseases from this study. At the same time of ultrasonic assessment, we check the stomach to confirm patient's compliance to nil per oral instruction. The FGBV is measured by the ellipsoid method wherein volume $=0.52$ (W $\times \mathrm{H} \times \mathrm{L}$ ), where $\mathrm{W}=$ gall bladder width, $\mathrm{H}=$ height, and $\mathrm{L}=$ length “17"”.The length of the gall bladder is obtained in the longitudinal scanning plane, while the width and height are taken in the transverse scanning plane. Then, the FGBV is computed from these three dimensions by the ultrasonic machine. Statistical analysis was done by using frequency and percentage, chi-square and fisher exact test had been used where P-value of $<0.05$ considered as significant level.

Results:In this study, there were 33 diabetic subjects without gallstones ( $69.7 \%$ of them were females and $30.3 \%$ were males). while in the other group of diabetic patients with gallstones (14 subjects), all of them (100\%) were females as shown in figure (1).

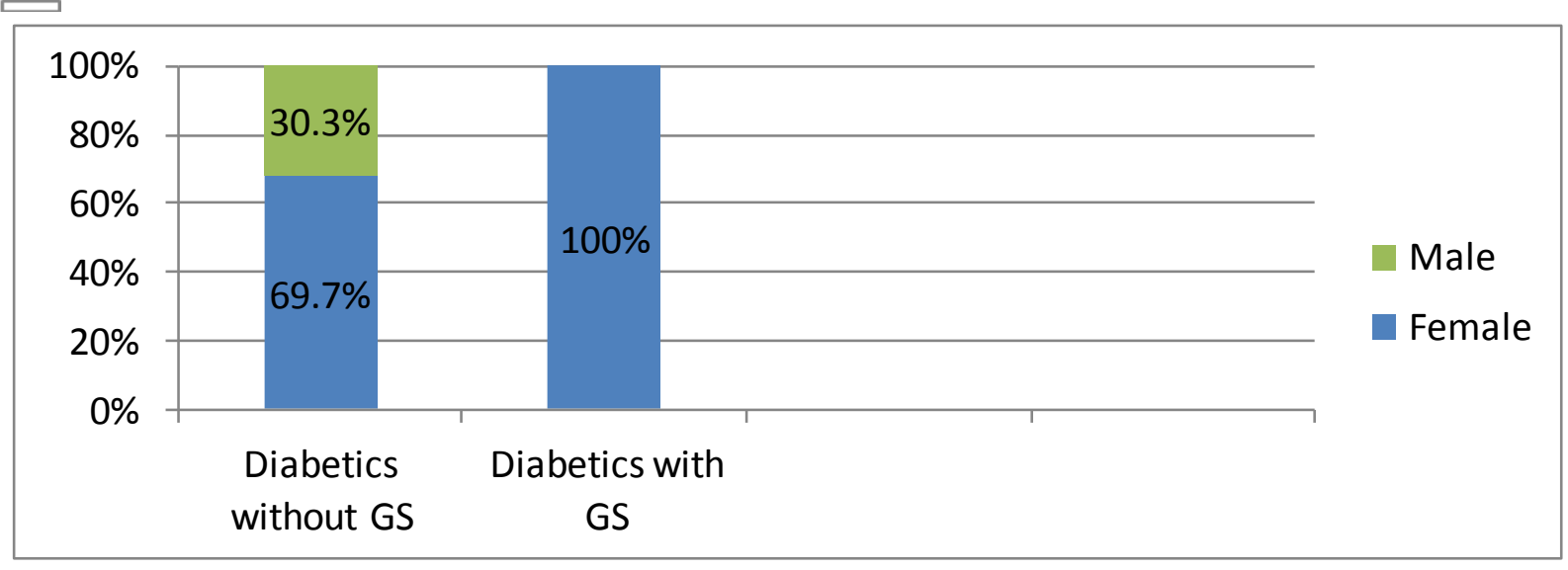

Figure 1. Gender distributio 
Table 1: Age distribution among diabetic patients according to gallstones.

\begin{tabular}{|l|l|l|l|}
\hline Group & \multicolumn{1}{|c|}{$\begin{array}{c}\text { Diabetics with } \\
\text { gallstones }\end{array}$} & $\begin{array}{c}\text { Diabetics without } \\
\text { gallstones }\end{array}$ & Row total \\
\hline $\mathbf{1 5 - 2 5}$ years & $1(7.1 \%)$ & $3(9.1 \%)$ & 4 \\
\hline $\mathbf{2 6 - 3 5}$ years & $1(7.1 \%)$ & $0(0 \%)$ & 12 \\
\hline $\mathbf{3 6 - 4 5}$ years & $6(43 \%)$ & $6(18.2 \%)$ & 16 \\
\hline $\mathbf{4 6 - 5 5}$ years & $1(7.1 \%)$ & $15(45.5 \%)$ & 12 \\
\hline $\mathbf{5 6 - 6 5}$ years & $5(35.7 \%)$ & $7(21.2 \%)$ & 2 \\
\hline$>\mathbf{6 5}$ years & $0(0 \%)$ & $2(6 \%)$ & Grand total $(47)$ \\
\hline Column total & $14(100 \%)$ & $33(100 \%)$ & 1 \\
\hline
\end{tabular}

p. value $=0.558$

The age range of the subjects is 19 to 75 years with a mean age of 47.5 year. In diabetics with gallstones, most of the patients (43\%) are in the age reference of ( 36-45 years), while most of the patients in diabetic group without gallstones $(45.5 \%)$ are in the age reference of (46-55 years) shown in table (1).

Table 2: Relationship between gender and gallstones among diabetic patients.

\begin{tabular}{|l|l|l|l|l|}
\hline Group & Females & Males & Row totals \\
\hline $\begin{array}{l}\text { Diabetics } \\
\text { with } \\
\text { gallstones }\end{array}$ & $14 \quad(100 \%)$ & 0 & $(0 \%)$ & $14 \quad(100 \%)$ \\
\hline $\begin{array}{l}\text { Diabetics } \\
\text { without } \\
\text { gallstones }\end{array}$ & $23 \quad(69.7 \%)$ & 10 & $(30.3 \%)$ & $33 \quad(100 \%)$ \\
\hline $\begin{array}{l}\text { Column } \\
\text { total }\end{array}$ & $37(78.7 \%)$ & $10(21.3 \%)$ & Grand total (47) $100 \%$ \\
\hline
\end{tabular}

p. value $=0.020$ 
Thi-Qar Medical Journal (TQMJ): Vol.(13), No.(1), 2017

Email:utjmed@utq.edu.iq

Web Site: $\underline{\text { https://imed.utq.edu.iq }}$

Table 3: The presence of gallstones in relation to BMI and lipid profile.

\begin{tabular}{|l|l|l|l|l|l|}
\hline BMI & \multicolumn{2}{|l|}{ Gallstones } & Lipid profile & \multicolumn{2}{l|}{ Gallstones } \\
\hline $\mathbf{K g} / \mathbf{m}^{\mathbf{2}}$ & Positive & Negative & & Positive & Negative \\
\hline $\mathbf{1 8 . 5}$ & 0 & 1 & Normal & 10 & 24 \\
\hline & $0 \%$ & $100 \%$ & & $29.4 \%$ & $70.6 \%$ \\
\hline $\mathbf{1 8 . 5 - 2 4 . 9}$ & 0 & 3 & Increased & 0 & 5 \\
\hline $\mathbf{2 5 - 2 9 . 9}$ & 4 & 13 & Increased & 2 & 3 \\
\hline $\mathbf{3 0 - 3 9 . 9}$ & $0 \%$ & $100 \%$ & Cholesterol & $0 \%$ & $100 \%$ \\
\hline $\mathbf{2 4 0}$ & $23.5 \%$ & $76.5 \%$ & TG & $40 \%$ & $60 \%$ \\
\hline & 0 & 13 & Increased & 2 & 1 \\
\hline & $0 \%$ & $100 \%$ & & $66.7 \%$ & $33.3 \%$ \\
\hline
\end{tabular}

p. value $=0.253$

p. value $=0.228$ 
Table 4: Gallstones in relation to duration and control of DM.

\begin{tabular}{|c|c|c|c|c|c|}
\hline \multirow{2}{*}{$\begin{array}{l}\text { Duration of } \\
\text { DM }\end{array}$} & \multicolumn{2}{|c|}{ Gallstones } & \multirow[t]{2}{*}{ HbA1c } & \multicolumn{2}{|c|}{ Gallstones } \\
\hline & positive & negative & & positive & negative \\
\hline \multirow[t]{2}{*}{$0-5$ years } & 4 & 17 & \multirow[t]{2}{*}{$<6.5 \%$} & 0 & 1 \\
\hline & $19 \%$ & $81 \%$ & & $0 \%$ & $100 \%$ \\
\hline \multirow[t]{2}{*}{ 6-10 years } & 8 & 13 & \multirow[t]{2}{*}{$6.5-7 \%$} & 0 & 2 \\
\hline & $38.1 \%$ & $61.9 \%$ & & $0 \%$ & $100 \%$ \\
\hline \multirow[t]{2}{*}{$11-15$ years } & 1 & 2 & \multirow[t]{2}{*}{$>7 \%$} & 14 & 30 \\
\hline & $33.3 \%$ & $66.7 \%$ & & $31.8 \%$ & $68.2 \%$ \\
\hline \multirow[t]{2}{*}{$16-20$ years } & 0 & 1 & & & \\
\hline & $0 \%$ & $100 \%$ & & & \\
\hline \multirow[t]{2}{*}{$>20$ years } & 1 & 0 & & & \\
\hline & $100 \%$ & $0 \%$ & & & \\
\hline
\end{tabular}

Table (4) shows that, most of diabetics without gallstones( $51.5 \%$ ) have duration of DM between 0-5 years, 39.5\% have duration of illness between 6-10 years , $6 \%$ have duration of DM between $11-15$ years, and only $3 \%$ of them with diabetes duration between $16-20$ years. While most of the diabetics with gallstones have DM duration between $6-10$ years $(57.2 \%), 28.6 \%$ of them have duration of illness between $0-5$ years, $7.1 \%$ of them have duration of DM between 11-15 years, and $7.1 \%$ have DM duration more than twenty years. Table (4) also explain that the HbA1c level is more than $7 \%$ in most of diabetics without gall stones $(90.9 \%),(6.1 \%)$ of them have a HbA1c level in the range of $6.5-7 \%$, and $(3 \%)$ have a HbA1c level less than $6.5 \%$. While, all diabetics with gallstones have HbA1c level of more than $7 \%$. Regarding cigarettes smoking history, all the diabetics with gallstones were nonsmoker. While $87.9 \%$ of the diabetic without gallstones were non-smoker, $9.1 \%$ of them 
Thi-Qar Medical Journal (TQMJ): Vol.(13), No.(1), 2017

Email:utjmed@utq.edu.iq

Web Site: https://imed.utq.edu.iq

were ex-smoker and 3\% of them were smoker with p. value (0.3955) as shown in figure (2).

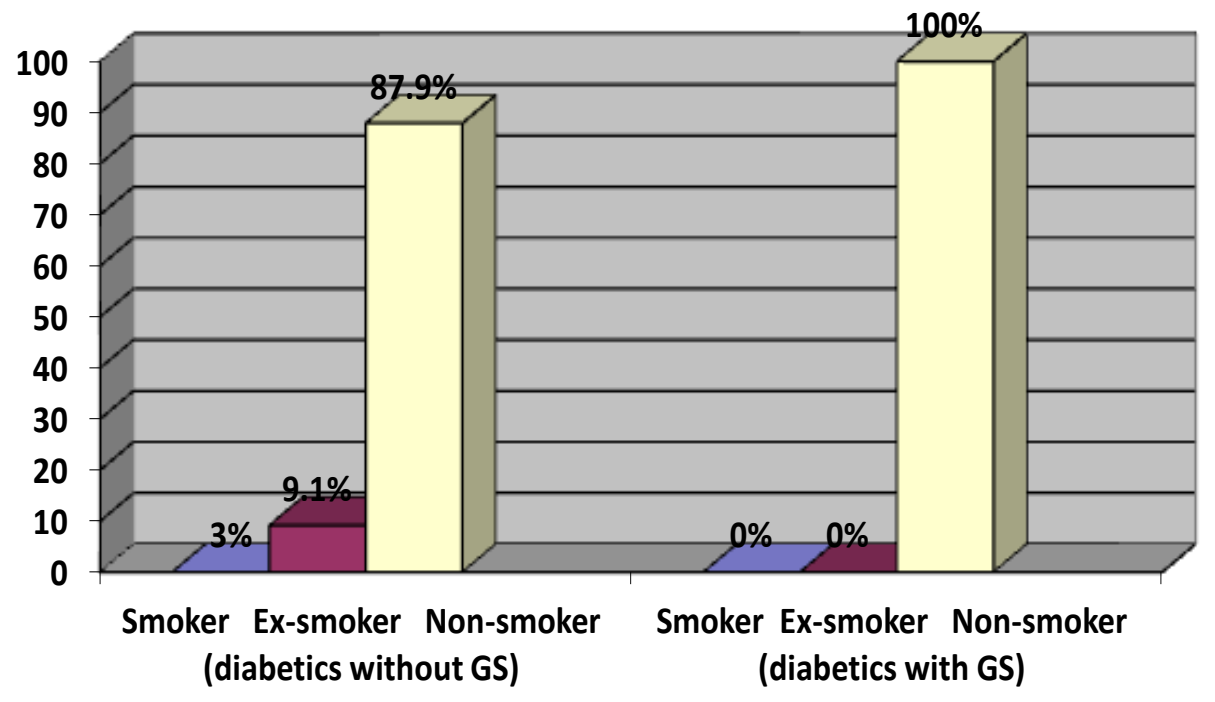

Figure 2. Cigarettes smoking in diabetics with GS and diabetics without GS

Table 5: relationship between family history of gallstones and gallstones prevalence among diabetic patients.

\begin{tabular}{|l|l|l|l|}
\hline Group & \multicolumn{1}{|c|}{$\begin{array}{c}\text { Positive family } \\
\text { history of GS }\end{array}$} & $\begin{array}{c}\text { Negative family } \\
\text { history of GS }\end{array}$ & Row total \\
\hline $\begin{array}{l}\text { Diabetics with } \\
\text { GS }\end{array}$ & 3 & 11 & 14 \\
\hline $\begin{array}{l}\text { Diabetics } \\
\text { without }\end{array}$ & $70 \%$ & $29.7 \%$ & 33 \\
\hline GS & $70 \%$ & 26 & \\
\hline Column total & $10(100 \%)$ & $70.3 \%$ & Grand total \\
\hline
\end{tabular}

p. value $=0.986$

Regarding the family history of gallstones, $(21.2 \%)$ of diabetic patients without gallstones have a family history of gallstones and (78.8\%) of them have no family history of gallstones. While in the diabetic group with gallstones, $(21.4 \%)$ of them have a family 
Thi-Qar Medical Journal (TQMJ): Vol.(13), No.(1), 2017

Email:utjmed@utq.edu.iq

Web Site: https://imed.utq.edu.iq

history of gallstones and $(78.6 \%)$ of them have no family history of gallstones as shown in table (5).

Table 6: Relationship between gallstones and FGBV .

\begin{tabular}{|c|c|c|c|}
\hline FGBV in $\mathbf{~ m l}^{3}$ & $\begin{array}{l}\text { Diabetics with } \\
\text { gallstones }\end{array}$ & $\begin{array}{l}\text { Diabetics without } \\
\text { gallstones }\end{array}$ & Row totals \\
\hline$\leq \mathbf{2 0}$ & $0 \quad(0 \%)$ & $20 \quad(100 \%)$ & $20(100 \%)$ \\
\hline 21-30 & $5 \quad(38.5 \%)$ & $8 \quad(61.5 \%)$ & $13(100 \%)$ \\
\hline $31-40$ & $5(62.5 \%)$ & $3 \quad(37.5 \%)$ & $8 \quad(100 \%)$ \\
\hline 41-50 & $1(33.3 \%)$ & $2 \quad(66.7 \%)$ & $3 \quad(100 \%)$ \\
\hline$>\mathbf{5 0}$ & $3(100 \%)$ & $0 \quad(0 \%)$ & $3(100 \%)$ \\
\hline Column total & 14 & 33 & Grand total (47) \\
\hline
\end{tabular}

p. value $=0.00047$

FGBV in most of the diabetics without gallstones (60.6\%) is less than $20 \mathrm{ml}^{3}, 24.2 \%$ of them have FGBV in the range reference of $(21-30) \mathrm{ml}^{3}, 9.1 \%$ have FGBV in the range reference of (31- 40) $\mathrm{ml}^{3}$, and $6.1 \%$ have FGBV in the reference range of (41- 50) $\mathrm{ml}^{3}$. On the other hand, $35.7 \%$ of diabetic patients with gallstones have a FGBV in the reference range of (21-30) $\mathrm{ml}^{3}, 35.7 \%$ of them have a FGBV in the reference range of $(31-40) \mathrm{ml}^{3}$, 7. $2 \%$ have a FGBV in the reference range of $(41-50) \mathrm{ml}^{3}$, and $21.4 \%$ have a FGBV more than $50 \mathrm{ml}^{3}$ as shown in table (6).

\section{Discussion:}

Diabetic patients appear to have an increased risk of developing gallstones "18". Female gender is one of the most important risk factors for gall stones forma-tion and the rates of gallstones are two to three times higher among women than men, but this is primarily a phenomenon of the childbearing age and sex hormones are most likely to be responsible for the increased risk because the estrogen

increases biliary cholesterol secretion causing cholesterol sequestration of bile " ${ }^{\text {(19", }}$. This cross sectional study that studied two diabetic groups, one of 


\section{Email:utjmed@utq.edu.iq}

them with gallstones and the other group have no gallstones, stated that:

In diabetics without gallstones, 69.7\% of the patients were women and 30.3 $\%$ were men with a ratio of $2.3: 1$, while all diabetics with gallstones $(100 \%)$ were women with a significant difference ( $\mathrm{P}$. value= 0.020) and this may be explained by the effect of estrogen hormone which increases biliary cholesterol secretion causing cholesterol sequestration of bile and may be due to small sample of patients included in this study.

Cholelithiasis is a disease of all age groups, but the peak incidence in diabetic patients was found in age group $60-69$ years and decline in the eighth decade “620".

This study shows that most of diabetics with gallstones $(42.8 \%)$ were in the age reference of(36- 45), while most diabetics without gallstones $(45.5 \%)$ were in the age reference of (46-55) with no significant difference (P-value= $0.558)$.

This study shows that, there is no significant correlation between the duration of DM and the prevalence of gallstones which is consistent with the result of a case control study done in Benghazi “21", which reported that the prevalence of gallstones in diabetics didn't affected by the duration of DM. So this study shows that, in diabetics without gallstones, the number of patients decreases as the duration of

\section{Web Site: https://imed.utq.edu.iq}

DM increase $51.5 \%$ of patients have duration of DM of 5 years or less, $39.5 \%$ of them have DM duration in the range of 6-10 years, $6 \%$ of them have DM duration in the range of 1115 years and $3 \%$ have duration of DM in the range of 16-20 years), while in the diabetic group with gallstones, (28.6\% of the patients have duration of diabetes in the range of 0-5 years and this percentage increase to $57.2 \%$ of patients with DM duration in the range of 6-10 years then the number of patients decrease as the diabetes duration increase as $7.1 \%$ of the patients have DM duration in the range of $11-15$ years and $7.1 \%$ of them have DM duration more than 20 years), with no significant difference between the two groups ( $\mathrm{P}$. value= $0.325)$.

Obesity is considered one of the most important risk factors associated with gallstones disease and it is very important mainly due to its increased pre-valence worldwide، ${ }^{\text {‘22”, }}$

Most of patients in the diabetic group without gallstones are obese $(39.4 \%)$ and over-weight (39.4\%), 9.1\% of them are morbidly obese, $9.1 \%$ of them have normal body BMI, and $3 \%$ of them are underweight. While most of diabetics with gallstones (71.5\%) are obese and $28.5 \%$ are overweight and there is no significant difference between the two groups ( $\mathrm{P}$. value $=0.253$ ). 


\section{Email:utjmed@utq.edu.iq}

High levels of HbA1c indicates poor glycemic control and many studies showed that, the prevalence of gallstones increased in diabetics with high levels of HbA1c and some studies "23" shows a high prevalence of gall stones among diabetics with high level of HbA1c in comparison with diabetics who have low levels of HbA1c.

In this study, most of diabetics without gallstones ( $90.9 \%)$ have poor glycemic control as they have HbA1c level of more than(7\%), $6.1 \%$ of them have fairly controlled blood sugar level with a HbA1c level in the range of $(6.5-7 \%)$, and only $3 \%$ of them have strictly controlled blood sugar level as they have a HbA1c level of less than (6.5\%), while all the diabetics with gallstones have poorly controlled blood sugar as they have a HbA1c levels of more than $7 \%$ with no significant difference between the two groups $(\mathrm{P}$. value $=0.506)$.

Poor blood sugar control in both groups may be due to poor education and life style modification (dietary regimen and exercise), noncompliance with oral anti-diabetic treatment, refusing insulin treatment and poor follow up.

Most “24,25,26”, but not all studies show a relationship of gallstone occurrence with a family history of the disease. In this study, only $21.2 \%$ of the diabetics without gallstones have family history of gallstones. on the other hand, only

\section{Web Site: https://imed.utq.edu.iq}

$21.4 \%$ of diabetics with gall-stones have family history of gallstones with no significant difference between the two groups $(\mathrm{P}$. value=0.986).

Despite of the identification of a positive correlation between serum TG and nucleation time of cholesterol in bile, a relationship between serum lipids and biliary cholesterol saturation index has not been identified “27”.

In this study, most of diabetics without gallstones(72.7\%)have normal serum cholesterol and TG levels, $15 \%$ of them have increased serum cholesterol only, $9 \%$ of them have increased serum TG only and $3.3 \%$ of them have increased both serum cholesterol and TG. While in the other group of diabetics with gallstones, $71.4 \%$ of them have normal serum cholesterol and TG, $14.3 \%$ of them have increased serum TG only and $14.3 \%$ have increased both serum cholesterol and TG with no significant difference between the two groups (P. value $=0.228$ ).

Our study showed no significant association between cigarettes smoking and the prevalence of asymptomatic gallstones in type 2 DM.

AK Agarwal et al showed that the mean FGBV was $18.20 \pm 2.54 \mathrm{ml}$ in type 1diabetics and25.87 $\pm 13.90 \mathrm{ml}$ in type 2 diabetics, with a minimum value of $9.30 \mathrm{ml}$ and maximum value of $88 \mathrm{ml}$. when type 2 diabetics were sub-grouped according to the presence 


\section{Email:utjmed@utq.edu.iq}

of autonomic neuropathy, higher gall bladder volumes were seen in patients with autonomic neuropathy “628,".

This study shows that, most of the diabetics without gallstones( $60.6 \%$ ) have a FGBV of less than $20 \mathrm{ml}$, $24.2 \%$ of them have a FGBV in the reference range of ( $20-30 \mathrm{ml}), 91 \%$ have a FGBV in the reference range of $(31-40 \mathrm{ml}$ ) and $6.1 \%$ have FGBV in the reference range of $(41-50 \mathrm{ml})$. While in diabetic group with gallstones, $35.7 \%$ of the patients have a FGBV in the reference range of ( 21 - $30 \mathrm{ml}), 35.7 \%$ have a FGBV in the reference range of (31- $40 \mathrm{ml}), 21.4 \%$ of them have a FGBV( more than 50 $\mathrm{ml}$ ) and $7.2 \%$ of them have FGBV in the reference range of $(40-50 \mathrm{ml})$ with significant difference between the two groups $(\mathrm{P}$. value $=0.0004)$, where the diabetic patients with gall-stones have much higher levels of FGBV than the diabetics group without gallstones ,so these results may reflect that the diabetic patients with gallstones (who have higher levels of FGBV than the diabetics without gallstones) have autonomic neuropathy which is attributing to gallbladder hypo-motility and leading to both increased FGBV and gallstones formation as a result of bile stasis.

Conclusion: The prevalence of asymptomatic gallstones is higher in diabetic patients with higher levels of fasting gall bladder volume than in diabetics with lower levels especially
Web Site: https://imed.utq.edu.iq

in women. So regular ultra-sonic screening of diabetic patients especially for those who have high levels of FGBV for the early detection of gallstones for early management to avoid their complications. Also the use of prokinetic drugs for diabetics with high levels of FGBV may reduce the incidence of gallstones by increasing the gallbladder motility.

\section{References}

1-Richard T Keays: Diabetic emergencies: Chapter 50; Intensive care manual-2009.

2-American Diabetes Association (2012). Diagnosis and classification of diabetes mellitus. Diabetes care, 35 (suppl 1) : S64 - S71.

3-Umesh Masharani, MB, BS, MRCP (UK): Diabetes mellitus and hypoglycemia: Chapter 27; Current medical diagnosis and treatment-2010.

4-Gordon N. Gill and David R. Clemmons: Priciples of endocrinology: chapter 240; Cecil textbook of medicine-2008.

5-R.W. Chapman, J.D. Coller, and P.C. Hayes: Liver and biliary tract disease: Chapter 23; p.990; Davidson's principles and practice of medicine- $20^{\text {th }}$ edition.

6-Shyam Varadarajuln, Rudolf GarciaGallont, and Michael B.Fallon: Disorders of the gall bladder and 
Thi-Qar Medical Journal (TQMJ): Vol.(13), No.(1), 2017

\section{Email:utjmed@utq.edu.iq}

biliary tract: Chapter 46; p.488; Cecil essentials of medicine- $8^{\text {th }}$ edition.

7-Type 2 DM-Medscape-2013.

8- Portincasa P, Moschetta A, Polasciano G. Cholesterol gallstone disease Lancet. Jul 15 2006; 363 (9531): $230-9$.

9-Ira M. Jacobson, MD: Gallstones: Chapter 50; Current diagnosis and treatment in gastroenterology- $2^{\text {nd }}$ edition.

10- Suzanne C. Smeltzer, Brenda G. Bare, Janice L. Hinkle, Kerry H. Cheever : Assessment and management of patients with biliary disorders: Chapter 40; P.1349; Brunner \& Suddarth's textbook of medical-surgical nursing- $11^{\text {th }}$ edition.

11- Pazzi P, Scagliarini R, Gamberini S, Pezzoli A. Review article: gallbladder motor function in diabetes mellitus.Aliment pharmacoal Ther. 2000; 14Suppl 2:62-65.

12- Liu CM, Tung TH, Liu JH, Lee WL, Chou P. A community-based epidemiologic study on gallstone disease among type 2diabetics in Kinmen, Taiwan. Dig Dis 2004; 22:87-91.

13- Kayacetin E, Kisakol G, Kaya A, Akpinar Z. real-time sonography for screening of gallbladder motility in diabetic patients:relation to autonomic and peripheral neuropathy. Neuro Endocrinol Lett. 2003; 24(1- 2): 7376.
Web Site: https://imed.utq.edu.iq

14- Keil R. The gallbladder, biliary tract, and diabetes mellitus. Vntrlek. 2004 ; 50(5): 383-385.

15- Olokoba AB, Bojuwoye BJ, Olokoba LB, Wahab KW, Salami AK, Braimoh KT, et al. The relationship between gallstone disease and gallbladder volume. Niger J Clin Pract. 2008; 11(2): 89-93.

16- Acharya SK. Diabetes mellitus and gastrointestinal system. In: Tripathy BB, Chandali HB, Das AK, Rao PV, Madhu SV, Mohan V (Eds). Rssdi: Textbook of Diabetes mellitus, Vol. 2,Jaypee Brothers Medical Publishers, 2012: pp: 939-949.

17- Soad M. A. Kishk, Reda M. A. Darweesh, Wylie J. Dodds, Thomas L. Lawson, Edward T. Stewart, Mark K. Kern, Effat H. Hassanein. Sonographic Evaluation of Resting Gallbladder Volume and Postprandial Emptying in Patients with gallstones. AJR: 148, May 1987.

18- Ruhl CE, Everhart JE. Association of diabetes, serum insulin, and Cpeptide with gallbladder disease. Hepatology 2000; 31: 299-303.

19- Novacek G. Gender and gallstone disease. Wien Med Wochenschr. 2006 oct ;156(19-20):527-33. Review. PMID: 17103289.

20- Bortoff GA, Chen MYM, Ott DJ, Wolfman NT, Routh WD. Gallblsdder stones: imaging and intervention. Radiographs 2000; 20:751-766. 
Thi-Qar Medical Journal (TQMJ): Vol.(13), No.(1), 2017

\section{Email:utjmed@utq.edu.iq}

21- Elmehdawi RR, Elmajberi SJ, Behieh A, Elramli A. Prevalence of gall bladder stones among type 2 diabetic patients in Benghazi Libya: A case-control study. Libyan J Med.2009;4(1):27-30.

22- Mendez-Sanchez N, Chavez-Tapia NC, Uribe M. Gallbladder disease and obesity. Gac Med Mex. 2004 Jul-Aug; 140 Suppl 2:S59-66.

23- Al-Bayati S, Kodayer S. Gallstones in a group of Iraqi patients with type 2 diabetes mellitus. Saudi Med J 2012; 33(4): 412-417.

24- Kratzer W, Kachele V, Mason RA, Hill V, Hay B, Haug C, Adler G, Beckh K, Muche R. Gallstone prevalence in Germany: the Ulm Gallbladder Stone Study. Dig Dis Sci 1998;43:1285-91.

25- Chapman BA, Frampton CM, Wilson IR, Chisholm RJ, Allan RB, Burt MJ. Gallstone prevalence in
Web Site: https://imed.utq.edu.iq

Christchurch: risk factors and clinical significance. N Z Med J 2000; 113: 46-8.

26- Attili AF, De Santis A, Attili F, Roda E, Festi D, Carulli N. Prevalence of gallstone disease in first-degree relatives of patients with cholelithiasis. World J Gastroenterol 2005;11:650811.

27- Janowitz P, Wechsler JG, Kuhn K, Kratzer W, Tudyka J, Swobodnik W, Ditschuneit H:The relationship between serum lipids, nucleation time, and biliary lipids in patients with gallstones. Clin investing.1992, 70: 430-436.PubMedView ArticleGoogle Scholar.

28- AK Agarwal, S Miglani, S Singla, U Garg, RK Dudeja, A Goel. Ultrasonic Evaluation of Gallbladder Volumein Diabetics. JAPI. VOL 52. December 2004. 
Thi-Qar Medical Journal (TQMJ): Vol.(13), No.(1), 2017

Email:utjmed@utq.edu.iq Web Site: https://imed.utq.edu.iq

\section{معدل انتشار حصى المرارة عديم الأعراض وعلاقته بالحجم ألصيامي للمرارة لاى مرضى السكري من النوع الثناتي}

عماد حاتم طاهر

خلاصة البحث

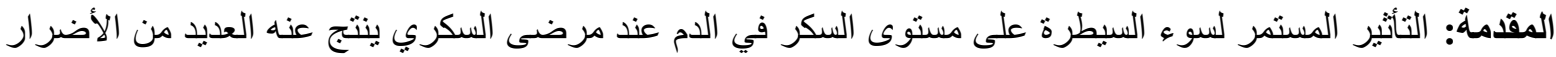

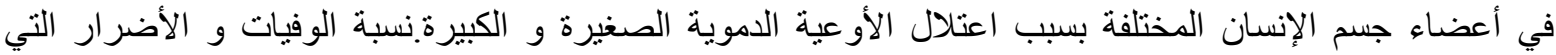

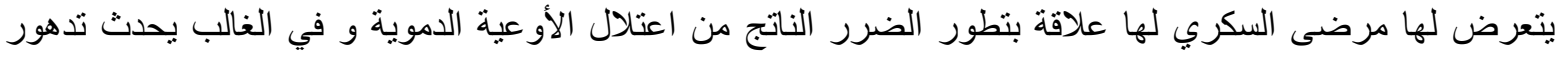

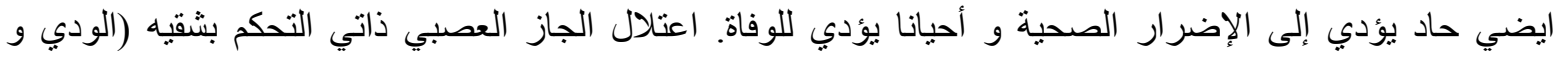

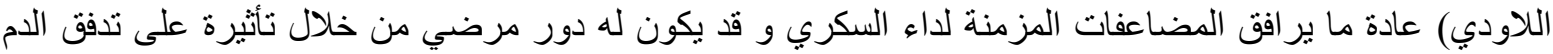

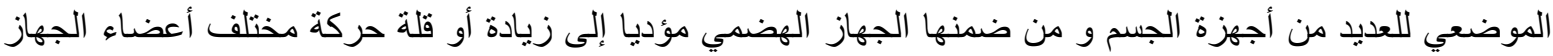

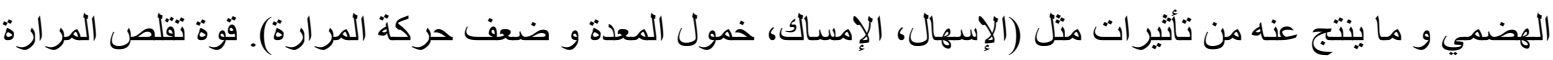

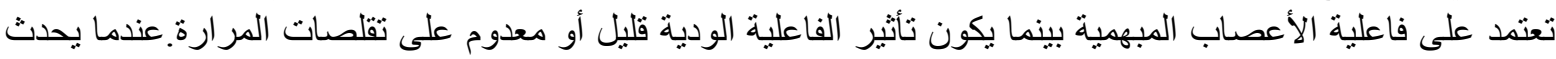

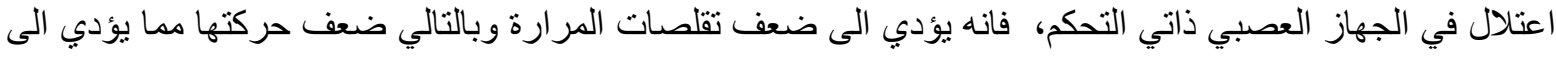

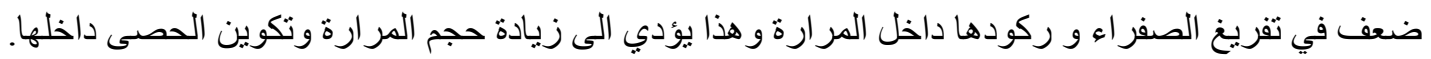

الغاية من البحث: لتقييم معدل انتشار حصى المرارة و علاقتها بالحجم ألصيامي للمرارة لاى مرضى السكري من النوع

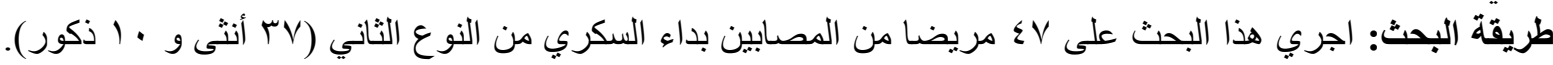

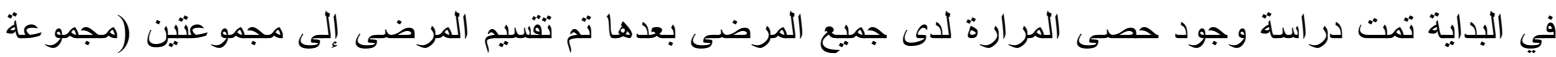

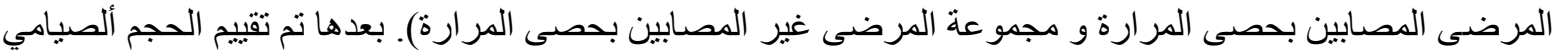

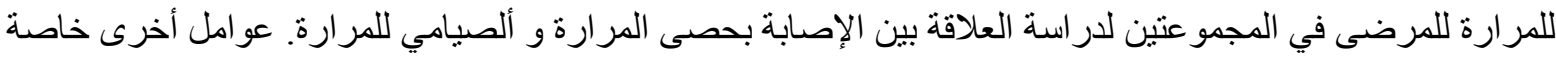

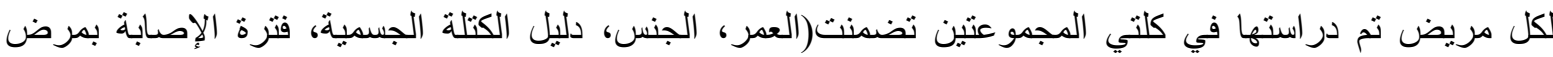

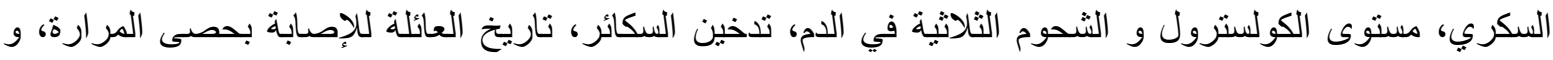

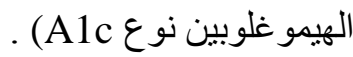

النتائج و المناقشة: من خلال هذا البحث الذي تناول مجمو عتين من مرضى السكري/ النوع الثاني (مجموعة المصابين

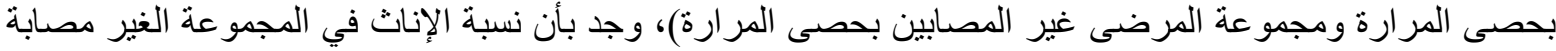

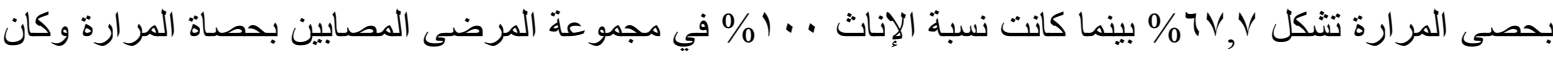
هذا الاختلاف بين المجموعتين قيما حيث كانت القيمة الاحتمالية (•r ·, •). بينما لم يكن هناللك علاقة قيمة بين معدل

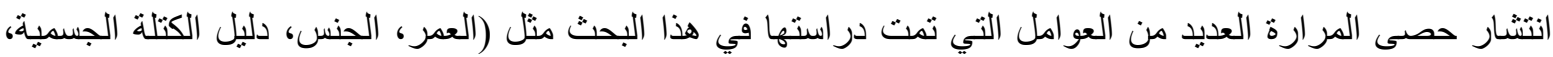

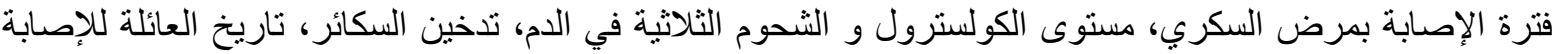

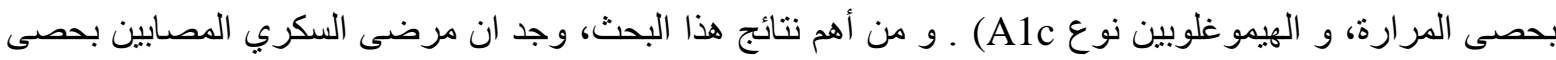

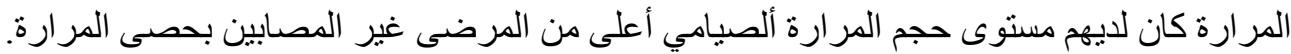


Thi-Qar Medical Journal (TQMJ): Vol.(13), No.(1), 2017

Email:utjmed@utq.edu.iq

Web Site: $\underline{\text { https://imed.utq.edu.iq }}$

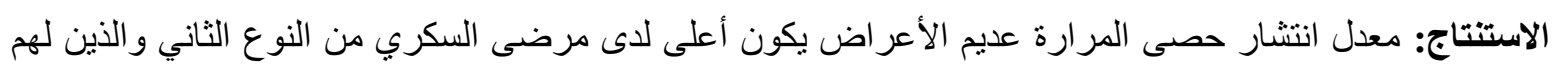
مستويات عالية من حجم المر ارة ألصيامي من الذين لهم مستويات أقل وخاصة المارئ المرضى الإناث. 